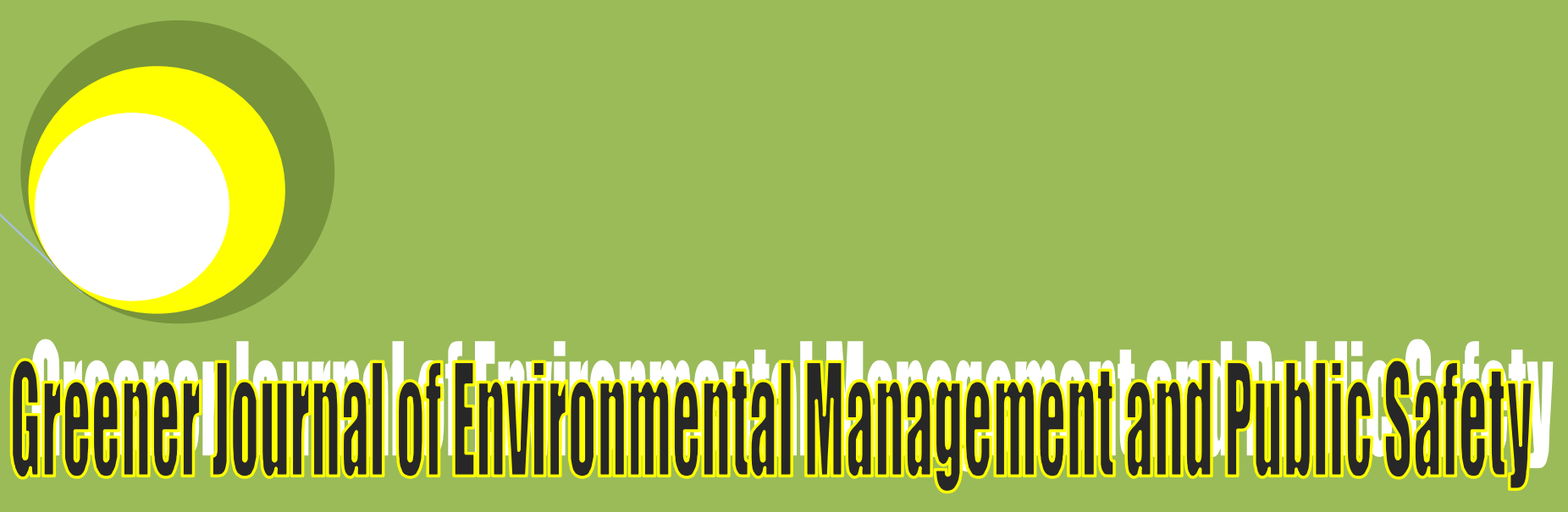

ISSN: 2354-2276

Submitted: $16 / 12 / 2016$

Accepted: 20/12/2016

Published: 27/12/2016

DOI: http://doi.org/10.15580/GJEMPS.2016.5.121616214

Spatial Variation in

Physico-chemical

Characteristics of

Sediment from Epie

Creek, Bayelsa State,

Nigeria

By

Enetimi Idah Seiyaboh

Iniobong Reuben Inyang

Sylvester Chibueze Izah 


\title{
Spatial Variation in Physico-chemical Characteristics of Sediment from Epie Creek, Bayelsa State, Nigeria
}

\section{Enetimi Idah Seiyaboh, Iniobong Reuben Inyang and Sylvester Chibueze Izah*}

\author{
Department of Biological Sciences, Faculty of Science, Niger Delta University, Wilberforce Island, Bayelsa State, \\ Nigeria
}

*Corresponding Author’s E-mail: chivestizah@ gmail.com

\begin{abstract}
This study assessed the spatial variation in physico-chemical properties of sediment along Epie creek, Niger Delta, Nigeria. Samples of the sediment were collected in triplicates from 5 different location along Epie creek using sediment grab. The samples were processed and analyzed using standard analytical methodology. Results revealed that the characteristics of the creek ranged from $6.67-6.77(\mathrm{pH}), 435.17-1189.50 \mu \mathrm{hmoscm}{ }^{-1}$ (conductivity), $0.39-1.05 \mathrm{mg} / \mathrm{kg}$ (nitrite), $2.87-7.59 \mathrm{mg} / \mathrm{kg}$ (nitrate), $1.06-3.81 \mathrm{mg} / \mathrm{kg}$ (sulphate), $0.09-0.42 \mathrm{mg} / \mathrm{kg}$ (phosphate), $3.92-6.88 \mathrm{mg} / \mathrm{kg}$ (calcium), $2.46-4.82 \mathrm{mg} / \mathrm{kg}$ (magnesium), $2.18-4.82 \mathrm{mg} / \mathrm{kg}$ (sodium), $1.59-3.34 \mathrm{mg} / \mathrm{kg}$ (potassium), $2.64-9.20 \%$ (total nitrogen), $8.48-22.54 \%$ (total organic carbon), total hydrocarbon level $(1.20-4.68 \mathrm{mg} / \mathrm{kg}$ ). Analysis of variance indicates that there is significance difference $(\mathrm{P}<0.05)$ among the various location for each of the parameters analyzed apart from $\mathrm{pH}$. Spatial variation suggests the influences of anthropogenic activities and wastes (from market and municipal) on the sediment and water quality.
\end{abstract}

Keywords: Bayelsa state, Epie Creek, Sediment quality

\section{INTRODUCTION}

Sediment quality is frequently assessed based on its biological, physical and chemical characteristics. Sediment studies suggests the characteristics of surface water. This is because substances such as organic and inorganic materials found in the aquatic ecosystem bed are sediment. The inorganic material includes fine material (such as clay, silt, and sand whose diameter is $<2 \mathrm{~mm}$ ); Coarse material (such as gravel, bedrock (RAMP, Undated). While the organic material (includes animal matter, aquatic plants, leaves, flowers, pollen, and even whole branches and trees) can be degraded by physical, chemical, and biological processes leading to formation of smaller organic particles to release of dissolved organic matter and nutrients (RAMP, Undated).

Water has a relationship with its sediment. The tendency of live to thrive in surface water depends on both water and its sediment features. Sediment characteristics of a water body depending mostly on drainage including natural and man-made. The drainage system of an area play essential role in the water quality within such area. The drainage of an area varies. For instance, in the Niger Delta region of Nigeria (a major world deltaic region) is a sedimentary basin. The Niger Delta spreads from Benin River in the west to Imo River in the east, and from Palm Point near Akassa in the south to Aboh in the north where the Niger River bifurcates into its two main tributaries (Peterside and Ogon, Undated). The Niger Delta has seven major drainage systems which lie squarely in the wet equatorial climatic belt. In Rivers and Bayelsa state, several rivers also abound but the predominant once are Orashi river (Rivers state) and River Nun (Bayelsa state). Several tributaries, creek and creeklets emanate from them and they are eventually discharged into the sea.

Each drainage feature affects the sediment characteristics of the surface water including species composition and abundance. Sediment has direct relationship with benthic organisms. This is because benthic organism resides in the benthic zone of the aquatic ecosystem. Most water pollutant end in the sediment. Sediment contamination is a big threat to the health status of aquatic organisms and humans that consumed aquatic organisms. As such, the assessment of sediment quality is an essential to environmentalist probably because of its complex nature which affects marine, estuarine and freshwater environments (Adesuyi et al., 2016)

In Bayelsa state, the characteristics of several surface water have been widely studied including Epie creek (Izonfuo and Bariweni, 2001). Epie creek aligns Yenegoa-Mbiama express way. The water is very resource full to the 
inhabitant of the area. Some of the uses of the creeks in Bayelsa state include fishing ground, transportation route and waste dumpsite for both municipal and market wastes. Sediment acts as a reservoir for pollutants which could affect the water column, organisms, and ultimately human that consumes organisms (Adesuyi et al., 2016). Several studies have been carried out with regard to sediment quality in Bayelsa state including lkoli creek (Seiyaboh et al., 2016), Igbedi creek (Seiyaboh et al., 2013). But information on sediment quality of Epie creek is Scarce in literature. Hence this study is aimed at evaluating the spatial distribution of sediment from Epie creek, Niger Delta Nigeria.

\section{MATERIALS AND METHOD}

\section{Study area}

Epie creek is an important creek aligning Yenagoa-Mbiama high way of Yenegoa metropolis, the Bayelsa state capital, Nigeria. Different waste streams are discharged into the creek. The creek water is used for drinking, bathing, recreational and transportation activities (Izonfuo and Bariweni, 2001). Like other region of the Niger Delta, two predominant seasons occurs in the region. The climate characteristics of the area have been widely reported by Ogamba et al. (2015a-c), Seiyaboh et al. (2016), Agedah et al. (2015), Aghoghovwia and Ohimain (2014).

\section{Sample collection and preparation}

Sediment sample from Epie creek was collected with Eckman sediment from 5 location including Amarata, Down Yenagoa, Onopa, Ovom and Tombia Junction in triplicate between June to August 2015. The samples were packaged with aluminum fossil and transported to the laboratory in an ice pack. Prior to analysis, the samples were air-dried and sieved using mesh.

\section{Physico-chemical analysis of the sediment}

The physico-chemical characteristics of the sediment samples were analyzed following standard procedure previously described by authors including $\mathrm{pH}$ (Bates, 1954), calcium, magnesium, potassium and calcium (Nwakaudu et al., 2012), organic carbon (Osuji and Adesiyan, 2005; Akubugwo et al., 2007), nitrates, phosphates and sulphates (Dewis and Freitas, 1970), nitrogen (Udoh and Ogunwale, 1986), conductivity (Aigberua et al., 2016). Total hydrocarbon content was analyzed using following ASTM D 9071B - 7 (Soxhlet Extraction Method).

\section{Statistical Analysis}

SPSS was used to carry out the statistical analysis. The mean value of the spatial variation was presented. One way analysis of variance was carried out at $P=0.05$. Observed differences between mean were discern using Duncan multiple range test statistics.

\section{RESULTS AND DISCUSSION}

The physicochemical properties of the sediment samples from Epie creek is presented in Table 1. The characteristics of the creek ranged from $6.67-6.77(\mathrm{pH}), 435.17-1189.50 \mu \mathrm{hmoscm}^{-1}$ (conductivity), $0.39-1.05 \mathrm{mg} / \mathrm{kg}$ (nitrite), $2.87-7.59 \mathrm{mg} / \mathrm{kg}$ (nitrate), $1.06-3.81 \mathrm{mg} / \mathrm{kg}$ (sulphate), $0.09-0.42 \mathrm{mg} / \mathrm{kg}$ (phosphate), $3.92-6.88 \mathrm{mg} / \mathrm{kg}$ (calcium), 2.46-4.82 mg/kg (magnesium), $2.18-4.82 \mathrm{mg} / \mathrm{kg}$ (sodium), $1.59-3.34 \mathrm{mg} / \mathrm{kg}$ (potassium), $2.64-9.20 \%$ (total nitrogen), $8.48-22.54 \%$ (total organic carbon), total hydrocarbon content $(1.20-4.68 \mathrm{mg} / \mathrm{kg}$ ). Apart from $\mathrm{pH}$, there was significance different $(\mathrm{P}<0.05)$ in the different locations for each of the physicochemical parameters. The variation in sediment physico-chemical quality may be associated differences in anthropogenic activities carried out at different part of the creek. The presence of aquatic plants i.e. macrophytes at some section of the creek could also lead to difference in sediment quality. Also, runoff of the different constituents into the creek during rainy season could also be cause of difference observed in for each of the parameters. The lack of variation in $\mathrm{pH}$ may be attributed to geological formation of the areas.

The differences in organic carbon could be associated variation in the deposition of organic matter at various locations (Adesuyi et al., 2016). Nutrient composition including anion and cation suggest that the sediment is rich. Specifically, nitrate and phosphates concentration suggests the nutrient level of the creek which could be associated to runoff after precipitation (Adesuyi et al., 2016). 
The findings of this study is has some similarity with previous work. For instance, Seiyaboh et al. (2016) reported lower conductivity, nitrite, nitrate, sulphate, magnesium, sodium, potassium, total nitrogen, carbon: nitrogen ratio; higher total hydrocarbon content; and comparable $\mathrm{pH}$, calcium and phosphate concentration sediment from Ikoli creek. The variation may be due to difference in anthropogenic activities in the creeks and effect on runoff on water quality and its sediment. Again, nature of the sediment and the organic matter composition, benthic community and structure could be the source of observed differences (Adesuyi et al., 2016).

Table 1: physico-chemical Parameters of sediment samples in Epie Creek

\begin{tabular}{|l|l|l|l|l|l|}
\hline Parameters & Amarata & $\begin{array}{l}\text { Down } \\
\text { Yenagoa }\end{array}$ & Onopa & Ovom & Tombia \\
\hline $\mathrm{pH}$ & $6.75^{\mathrm{a}}$ & $6.67^{\mathrm{a}}$ & $6.77^{\mathrm{a}}$ & $6.77^{\mathrm{a}}$ & $6.73^{\mathrm{a}}$ \\
\hline Conductivity, $\mu \mathrm{hmoscm}{ }^{-1}$ & $753.00^{\mathrm{b}}$ & $1189.50^{\mathrm{d}}$ & $920.00^{\mathrm{c}}$ & $928.00^{\mathrm{c}}$ & $435.17^{\mathrm{a}}$ \\
\hline Nitrite, $\mathrm{mg} / \mathrm{kg}$ & $0.62^{\mathrm{b}}$ & $1.05^{\mathrm{e}}$ & $0.85^{\mathrm{c}}$ & $0.85^{\mathrm{d}}$ & $0.39^{\mathrm{a}}$ \\
\hline Nitrate, $\mathrm{mg} / \mathrm{kg}$ & $4.39^{\mathrm{b}}$ & $7.59^{\mathrm{e}}$ & $5.91^{\mathrm{d}}$ & $5.28^{\mathrm{c}}$ & $2.87^{\mathrm{a}}$ \\
\hline Sulphate, $\mathrm{mg} / \mathrm{kg}$ & $2.01^{\mathrm{b}}$ & $3.81^{\mathrm{e}}$ & $2.72^{\mathrm{d}}$ & $2.58^{\mathrm{c}}$ & $1.06^{\mathrm{a}}$ \\
\hline Phosphate, $\mathrm{mg} / \mathrm{kg}$ & $0.23^{\mathrm{c}}$ & $0.17^{\mathrm{b}}$ & $0.09^{\mathrm{a}}$ & $0.42^{\mathrm{d}}$ & $0.17^{\mathrm{b}}$ \\
\hline Calcium, mg/kg & $5.41^{\mathrm{b}}$ & $6.88^{\mathrm{e}}$ & $6.23^{\mathrm{d}}$ & $5.70^{\mathrm{c}}$ & $3.92^{\mathrm{a}}$ \\
\hline Magnesium, mg/kg & $3.92^{\mathrm{a}}$ & $4.82^{\mathrm{d}}$ & $4.52^{\mathrm{c}}$ & $3.72^{\mathrm{a}}$ & $2.46^{\mathrm{a}}$ \\
\hline Sodium, mg/kg & $4.04^{\mathrm{b}}$ & $4.82^{\mathrm{c}}$ & $4.57^{\mathrm{c}}$ & $4.07^{\mathrm{b}}$ & $2.18^{\mathrm{a}}$ \\
\hline Potassium, $\mathrm{mg} / \mathrm{kg}$ & $2.99^{\mathrm{c}}$ & $3.34^{\mathrm{e}}$ & $3.13^{\mathrm{d}}$ & $2.46^{\mathrm{b}}$ & $1.59^{\mathrm{a}}$ \\
\hline Total nitrogen,\% & $5.82^{\mathrm{b}}$ & $9.20^{\mathrm{c}}$ & $5.68^{\mathrm{b}}$ & $5.42^{\mathrm{b}}$ & $2.64^{\mathrm{a}}$ \\
\hline Organic carbon, \% & $8.48^{\mathrm{a}}$ & $22.54^{\mathrm{c}}$ & $13.47^{\mathrm{b}}$ & $11.41^{\mathrm{b}}$ & $8.97^{\mathrm{a}}$ \\
\hline C:N & $3.19^{\mathrm{a}}$ & $3.64^{\mathrm{b}}$ & $4.16^{\mathrm{c}}$ & $3.99^{\mathrm{c}}$ & $3.47^{\mathrm{b}}$ \\
\hline $\begin{array}{l}\text { Total hydrocarbon content, } \\
\text { mg/kg }\end{array}$ & $3.47^{\mathrm{bc}}$ & $4.68^{\mathrm{c}}$ & $2.81^{\mathrm{b}}$ & $2.48^{\mathrm{ab}}$ & $1.20^{\mathrm{a}}$ \\
\hline
\end{tabular}

Different superscript letters along the row indicate significance difference $(P<0.05)$ according to Duncan statistics

\section{CONCLUSION}

Sediment is one of the essential characteristics used in assessing the suitability of water for its biota. Sediment is also used to assess pollution indices of the water. This study evaluated spatial variation in physico-chemical quality of sediment from Epie creek, Niger Delta. The parameters studied showed significance difference $(P<0.05)$ among the various location suggest effect of point runoff and wastes (market and municipal) discharged at different position along the creek.

\section{REFERENCES}

Adesuyi, A.A., Ngwoke, M.O., Akinola, M.O., Njoku, K.L. and Jolaoso, A.O. (2016). Assessment of Physicochemical Characteristics of Sediment from Nwaja Creek, Niger Delta, Nigeria. Geoscience and Environment Protection, 4: 16-27.

Agedah, E.C., Ineyougha, E.R., Izah, S.C., and Orutugu, L.A. (2015). Enumeration of total heterotrophic bacteria and some physico-chemical characteristics of surface water used for drinking sources in Wilberforce Island, Nigeria. Journal of Environmental Treatment Techniques, 3(1): 28 - 34.

Aghoghovwia, O. A. and Ohimain, E. I. (2014). Physicochemical characteristics of lower Kolo creek, Otuogidi, Bayelsa state. Nigerian Journal of Agriculture, Food and Environment, 10(1):23 - 26.

Akubugwo, I.E., Ofoegbu, C.J. and Ukuoma, C.U. (2007). physiochemical studies on Uburu salt lake, Ebonyi State Nigeria. Pakistan Journal of Biological Sciences, 10(18):3170-3174

Bates, R.G. (1954). Electrometric pH determinations John Willey and Sons Inc. New York.

Dewis, J. and Fretias, F. (1970). Physical and Chemical Methods of Soil and water analysis. Soil Bulletin 10. FAD ROME. 
Izonfuo, L.W.A. and Bariweni, A. P. (2001). The effect of urban runoff water and human activities on some physicochemical parameters of the Epie Creek in the Niger Delta. Journal of Applied Sciences and Environmental Management, 5(1):47-55.

Nwakaudu, M.S., Kamen, F.L., Afube, G., and Nwakaudu, A.A., Ike, I.S. (2012). Impact of Cassava Processing Effluent on Agricultural Soil: A Case Study of Maize Growth. Journal of Emerging Trends in Engineering and Applied Sciences, 3(5): 881-885

Ogamba EN, Izah SC and Oribu T. (2015a). Water quality and proximate analysis of Eichhornia crassipes from River Nun, Amassoma Axis, Nigeria. Research Journal of Phytomedicine, 1(1): 43 - 48.

Ogamba, E.N., Izah, S.C. and Toikumo, B.P. (2015b). Water quality and levels of lead and mercury in Eichhornia crassipes from a tidal creek receiving abattoir effluent, in the Niger Delta, Nigeria. Continental Journal of Environmental Science, 9(1): $13-25$.

Ogamba, E.N., Seiyaboh, E.I., Izah, S.C., Ogbugo, I. and Demedongha, F.K. (2015c). Water quality, phytochemistry and proximate constituents of Eichhornia crassipes from Kolo creek, Niger Delta, Nigeria. International Journal of Applied Research and Technology, 4(9): 77 - 84.

Osuji, L.C. and Adesiyan, S.O. (2005). The Isiokpo oil pipeline leakage. Total organic carbon/organic matter contents of affected soils. Chemical Biodiversity 2: 1079-1085.

Peterside S. and Ogon P. (Undated). Background paper: the Niger Delta. http://globetrotter.berkeley.edu/GreenGovernance/papers/Nigeriabckgrd.pdf . Accessed September $21^{\text {st }} 2016$.

Regional Aqutic Monitoring Programme (RAMP) (Undated). Sediment Quality Indicators http://www.rampalberta.org/river/water+sediment+quality/soil.aspx. Accessed December $11^{\text {th }} 2016$.

Seiyaboh, E.I., Ogamba, E.N. and Utibe, D.I. (2013). Impact of Dredging on the Sediment Quality of Igbedi Creek, Upper Nun River in Central Niger Delta, Nigeria. IOSR Journal of Environmental Science, Toxicology and Food Technology, 7(5): 45-50.

Seiyaboh, E.I., Inyang, I.R. and Izah, S.C. (2016). Seasonal variation of physico-chemical quality of sediment from Ikoli creek, Niger Delta. International Journal of Innovative Environmental Studies Research, 4(4): 29-34.

Udoh, J.E. and Ogunwale, L,M. (1986). Laboratory Manual for analysis of soil, plant and water samples. University Press Ibadan 151-162.

Cite this Article: Seiyaboh EI, Inyang IR and Izah SC (2016). Spatial Variation in Physico-chemical Characteristics of Sediment from Epie Creek, Bayelsa State, Nigeria. Greener Journal of Environmental Management and Public Safety, 5(5): 100-103, http://doi.org/10.15580/GJEMPS.2016.5.121616214 